\title{
Gender Gap in Repartnering: The Role of Parental Status and Custodial Arrangements
}

\begin{abstract}
Objective: This study assesses whether parenthood influences repartnering for women and men and explores how repartnering is associated with parental status of the prospective partners.
\end{abstract}

Background: Previous research has not demonstrated whether gender differences in repartnering are conditional on the presence of children. This study aims to better disentangle the specific gender differentials in repartnering probabilities conditional on parenthood and child custody status.

Method: The analytical sample consists of 5,372 women and 3,375 men who reported at least one partnership dissolution in the British Understanding Society survey. Multilevel event history models with Markov Chain Monte Carlo simulations are used to estimate the probabilities of (a) finding a new partner and (b) finding a new childless partner or a new partner who has children.

Results: The results suggest that mothers, and to a lesser extent fathers, are less likely to repartner than their childless counterparts. Among parents who have child custody, there emerges a distinct gender gap because mothers exhibit a significantly lower rate of repartnering than

\footnotetext{
Life Course and Inequality Research Centre, University of Lausanne, Geopolis Building, CH-1015 Lausanne, Switzerland. (alessandro.dinallo@unil.ch).

*Universitat Pompeu Fabra, Carrer de Ramon Trias Fargas, 25, 08005 Barcelona, Spain.
}

Key Words: children, gender, living arrangements, multilevel models, remarriage, stepfamilies. fathers. Finally, coresident single parents are relatively less likely to repartner with childless individuals, and single fathers more frequently form two-parent stepfamilies than do mothers.

Conclusion: This suggests the presence of a gender divide in repartnering that is especially apparent when child custody is taken into account. The presence of children also reduces the possibility of forming unions with childless individuals.

The rise in cohabitation, divorce, and separation coupled with the higher frequency of repartnering has produced greater diversity in partnering trajectories in most European countries. During the past decades, both men and women are increasingly likely to enter into higher order unions (Elzinga \& Liefbroer, 2007), and this is also true across a wider age span (Beaujouan, 2012). The transition out of a partnership and into a new one has implications for the psychological readjustment of expartners (e.g., Tavares \& Aassve, 2013; Wang \& Amato, 2000) for dependent children's well-being (Amato \& Kane, 2011), and for the formation of stepfamilies. Compared to childless couples, unions with stepchildren are more complex institutions and might be affected by a lack of clarity of the roles within the family (Sweeney, 2010). Thus, the issue of who forms higher order unions and what role children play in shaping their parents' behavior is relevant for family functioning (Brown \& Manning, 2009; Stewart, 2005).

Existing research on repartnering behavior has primarily focused on women and has shown 
that after a separation or a divorce, mothers are less likely to form a new partnership with respect to childless women (e.g., Beaujouan, 2012; Wu \& Schimmele, 2005). Evidence for children's roles in repartnering among men is more limited and inconsistent due to the lack of detailed measures for father-child contact after union dissolution. Consequently, there is little evidence on intergender differences in repartnering by parental status (childless vs. parents) and by children's residential status (e.g., coresident vs. nonresident). Furthermore, there has been little research into whether repartnering behavior is influenced by the parental status of perspective partners, and it remains unclear how family formation varies by gender.

This study seeks to fill these gaps by assessing both how parental status is linked to entry into a new union and whether the union that is formed includes the partner's children. The first part of the analysis examines whether children's residential status, number, and age are associated with lower chances of a new union for separated parents when compared with their childless peers. The second part addresses the question of the influence of (own) children and a prospective partner's children on the likelihood of women and men forming a union, either with a childless individual or with a parent. Both analyses will contribute to the literature by assessing the existence of systematic gender differences in these repartnering patterns.

Drawing on data from the British Understanding Society survey, this study considers the repartnering process after first and higher order marital and cohabiting union dissolutions during ages 18 to 50 . The focus on all episodes of singlehood during a life course, in contrast to most existing research, is motivated by the increasing prevalence of individuals in multiple relationships (marriage and cohabitation) in Britain (Beaujouan \& Ní Bhrolcháin, 2011; Sanchez Gassen \& Perelli-Harris, 2015). Furthermore, the data structure-with multiple episodes of singlehood nested within the same individual-requires standard multilevel event-history models combined with a multilevel approach and Markov Chain Monte-Carlo simulations. The advantage of these frailty models is that they explicitly address the issue of self-selection on unmeasured characteristics associated with union entry and exit (Allison, 1982).

\section{BACKGROUND}

\section{Repartnering, Predictors, and Gender Differences}

Partnership trajectories have become increasingly complex as life-time marriages have become less common (Elzinga \& Liefbroer, 2007) and as cohabitation has gradually been chosen as an alternative to marriage (e.g., Murphy, 2000; Perelli-Harris, 2014). Serial coresidential partnership has increased in European countries during the past 4 decades and Britain has one of the highest rates of partnership turnout (Gałęzewska, Perelli-Harris, \& Berrington, 2017; Perelli-Harris et al., 2012). Women and men who experienced at least one partnership break-up accounted for between $30 \%$ and $40 \%$ of those born between 1945 and 1970, and about two thirds of women and three quarters of men found a new partner (Beaujouan \& Ní Bhrolcháin, 2011). It is also clear that the rise in serial coresident partnerships has been driven by cohabitation rather than by marriages (Berrington \& Stone, 2017) and has increasingly involved children born within dissolved unions (Boertien, 2016).

Empirical evidence shows that there are important differences in how men and women repartner (Wu \& Schimmele, 2005). Overall, men are more likely to repartner, with shorter spells between two consecutive unions (e.g., de Graaf \& Kalmijn, 2003; Poortman, 2007; Wu \& Schimmele, 2005). This difference widens with age (Beaujouan, 2012). In fact, marriage market mechanisms work in favor of men, who tend to find partners across a larger age range (Gelissen, 2004; Goldscheider \& Sassler, 2006) and might have a later schedule of family formation or reformation (Beaujouan, 2012; Lampard \& Peggs, 1999). Past union experiences may also affect men and women differently. The demise of a union arguably hits women harder than men, particularly when it comes to the impact of prior unions and the duration of the union (Poortman, 2007). Women might be more prone to bear the emotional burden of a dissolution and might generally have less desire for a new relationship (Beaujouan, 2012).

Existing research has generally looked at second union formation after a divorce and neglected higher order and postcohabitation repartnering for both men and women. The first contribution of this study will be to fill this gap by looking at the formation of second and 
higher order unions for both men and women. By including the type and duration of previous unions, and the length of previous periods of singlehood for repeating events, it is possible to gain more knowledge about the cumulative influence of experiences of new union formation and to highlight gender differences.

\section{The Role of Parenthood, Parental Custody, and Children's Characteristics in Repartnering}

Parenthood is a key factor for intragender (mothers vs. childless women) and intergender (mothers vs. fathers) differentials (de Graaf \& Kalmijn, 2003; Goldscheider \& Sassler, 2006; Poortman, 2007; Wu \& Schimmele, 2005). Mothers are significantly less likely to repartner than childless women (e.g., Beaujouan, 2012; de Graaf \& Kalmijn, 2003; Steele, Kallis, Goldstein, \& Joshi, 2005; Wu \& Schimmele, 2005). This is especially the case for women with many (and young) children (Ivanova, Kalmijn, \& Uunk, 2013; Poortman, 2007) and for women with a nonmarital first birth (Upchurch, Lillard, \& Panis, 2002).

A few studies have analyzed how fatherhood influences men's new union prospects, but the evidence does not show any clear gap between childless men and fathers. Under certain circumstances, fathers are more likely to enter a union than childless men because fathers seem to be understood to be more reliable partners (Goldscheider \& Sassler, 2006; Wu \& Schimmele, 2005). Other studies have found no or a nonsignificant difference in partnering probabilities between fathers and childless men (e.g., de Graaf \& Kalmijn, 2003; Ivanova et al., 2013; Sweeney, 1997; Skew, Evans, \& Gray, 2009). These findings do not clarify to what extent repartnering patterns are attributable to gender, parental status (parents vs. childless), and children's residence status (coresident vs. nonresident), not to mention data limitations concerning children's characteristics (Beaujouan, 2012; Poortman, 2007; Goldscheider \& Sassler, 2006; Sweeney, 1997; Wu \& Schimmele, 2005). The second contribution of this study is to include a wider and more accurate array of information for children, such as their residence status, age, and number, thus disentangling, in terms of repartnering possibilities, the role of parenthood, and children's residence, from gender.
There are three arguments which can explain the role of children in the repartnering process and the diverse responses of men and women to union prospects: opportunity, attractiveness, and need (e.g., Becker, 1981; de Graaf \& Kalmijn, 2003; Ivanova et al., 2013; Kalmijn, 1998; Vanassche, Corijn, Matthijs, \& Swicegood, 2015). Table 1 summarizes the mechanisms leading to an increase (or a decrease) in the probability of union formation. From the combination of these mechanisms, I offer three distinct hypotheses on the roles of the following: (a) individuals' parental status (coresident vs. nonresident parents and childless individuals), (b) parents' gender and residence status (coresident mothers vs. fathers), and (c) children's age and number.

The first argument affirms that financial commitments and time dedication to child care reduce a parent's opportunities for finding a new partner (Koo, Suchindran, \& Griffith, 1984), especially if there is more than one dependent child and even more so if all or some of these are still very young (e.g., Huerta et al., 2013). This reasoning should apply to a lesser extent to nonresident parents, although their visitation schedule and paternal duties, if any, may dissuade them from planning a new union (Lampard \& Peggs, 1999). In Britain, where legislation encourages separated or divorced parents to negotiate children's arrangements through private agreements, mothers generally retain physical custody of the children (Blackwell \& Dawe, 2003; Hunt \& Roberts, 2004), whereas fathers are more likely to commit to temporary stays and financial help (Blackwell \& Dawe, 2003; Harding \& Newnham, 2015; Trinder, 2010). Similar numbers of fathers, ranging from $9 \%$ to $12 \%$, are involved in children's shared (Trinder, 2010) and exclusive custody (Blackwell \& Dawe, 2003; Peacey \& Hunt, 2009), whereas around $10 \%$ of fathers, according to recent estimates (Poole, Speight, O'Brien, Connolly, \& Aldrich, 2015), lose touch with their children altogether (as opposed to roughly $40 \%$ in the 1980s; Bradshaw \& Miller, 1991). Hence, in Britain, a substantial proportion of adults at risk of entering a new coresidential union have children, either living with them or tied to them emotionally and financially, with the caretaking burden falling disproportionately on women.

The second argument holds that having a child decreases one's attractiveness to new 
Table 1. Summary of Mechanisms of Union Formation With Respect to Three Motives (Needs, Attractiveness, and Opportunity), by Parental Status

\begin{tabular}{|c|c|c|c|c|}
\hline Own parental status $\rightarrow$ & & Childless person & Nonresident parent & Coresident parent \\
\hline \multirow[t]{3}{*}{$\begin{array}{l}\text { Probability of } \\
\text { repartnering }\end{array}$} & Opportunity & + No time constraints & $\begin{array}{l}\text { - Time constraints (children: } \\
\text { number \& young age) }\end{array}$ & $\begin{array}{l}\text { - Time constraints (children: } \\
\text { number \& young age) }\end{array}$ \\
\hline & Attractiveness & + No stepparenthood & $\begin{array}{l}\text { - Stepparenthood/part-time } \\
\text { stepfamily formation ( } ₫ \\
\text { mainly) } \\
\text { - Left custody of child ( }+ \\
\text { mainly) }\end{array}$ & $\begin{array}{l}\text { - Stepparenthood/stepfamily } \\
\text { formation (o mainly) } \\
+ \text { "Good father" (ðð only) }\end{array}$ \\
\hline & Need & + Partnership & 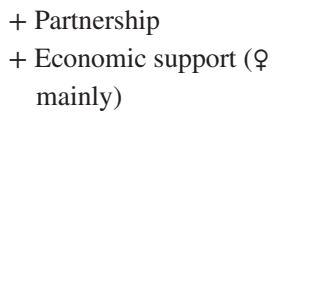 & $\begin{array}{l}+ \text { Partnership } \\
\text { - Child-care routine } \\
\text { interference ( } \odot \text { mainly) } \\
+ \text { Economic support ( } q \\
\text { mainly) } \\
+ \text { Childrearing support for } \\
\text { toddlers \& infants ( } ₫ \\
\text { mainly) }\end{array}$ \\
\hline
\end{tabular}

Note. + or - indicate a mechanism that leads to an increase or a decrease in the likelihood of new union formation.

potential partners. The presence of a child from a previous union may signal ongoing contact with the former partner (Monte, 2007) and scare away potential future stepparents (Stewart, Manning, \& Smock, 2003). This motivation might vary by gender as previous studies on the mating process reveal asymmetric preferences: Women are more inclined to form unions with partners who have children than are men (Bernhardt \& Goldscheider, 2002; South, 1991). An explanation from the anthropology literature views women's child-care involvement as being less dependent on genetic inheritance than men's (Hofferth \& Anderson, 2003; Waynforth, 2013). An alternative hypothesis (the "good father effect") depicts custodial fathers-as opposed to childless men and nonresident fathers-as impressing with commitment to their children's care and their dependability in a prospective family (Lappegård \& Rønsen, 2013). Conversely, custody is considered normative for women and any retreat from maternal responsibilities may even hamper women's repartnering prospects.

The third argument emphasizes different factors that spur mothers and fathers to find a new partner. The need for a new partner may arise so as to compensate for financial loss (Jansen, Wijckmans, \& Van Bavel, 2009), the psychological distress caused by a separation
(Wang \& Amato, 2000), or distance from children (Tavares \& Aassve, 2013). The mechanisms could be gender specific. On one hand, women might be more financially affected by a union dissolution than men, especially if they have dependent children (Dykstra \& Poortman, 2010). On the other hand, separated mothers are less inclined to repartner when compared with childless women, as they fear a new partner's interference with their established child-care routine (Beaujouan, 2012). Conversely, fathers with dependent children might purposely search for a new partner who could take on the role of stepmother and become a surrogate for a missing maternal figure (Bernhardt \& Goldscheider, 2002).

Taking these three motives together, I expect coresident parents to be less likely to repartner than nonresident parents and childless individuals (Hypothesis 1). Parents living with dependent children might have lower chances of a new partnership relative to nonresident parents and childless individuals. This might be so either because they have fewer opportunities to find new partners (the opportunity hypothesis) or because potential partners might prove reluctant to take on the role of stepparents (the attractiveness hypothesis). I also hypothesise that coresident mothers are less likely to repartner than coresident fathers (Hypothesis 2). Children may be less of an obstacle to a new union for coresident fathers, who arguably benefit from 
the extra bonus of "good-father" reliability (the attractiveness hypothesis) and who might be more motivated to search for a partner (the need hypothesis) than custodial mothers. Together with children's residence status, two other child characteristics should help disentangle these conflicting expectations. I expect the number of children to be negatively associated with the chances of repartnering (Hypothesis 3a), whereas the age of children could be either positively or negatively associated with the chances of repartnering (Hypothesis 3b). The number of children is positively associated with parents' time constraints for social activities (the opportunity hypothesis), whereas the age of the youngest child could either further limit time availability for custodial parents (the opportunity hypothesis) or urge fathers (more than mothers) to find childrearing support in a new partnership (the need hypothesis).

\section{The Role of Partners' Parental Status}

The second part of the analysis explores how likely different parental statuses (coresident parent vs. nonresident parent and the childless) are to form a simple or a complex stepfamily or a childless union. Two partners form a stepfamily if at least one of them brings children to the new union. If the children in a stepfamily are biologically linked to only one partner, this new union is a "simple stepfamily." If both partners bring children into the new family, they form a "complex stepfamily" (Sweeney, 2010, p. 670), and both assume the role of stepparent.

Table 2 provides a summary of the key theoretical arguments, besides those stated previously, on the interplay of the parental status of both partners along with the residential arrangements for their children. I then illustrate two hypotheses on the association of individual parental status (coresident and nonresident parenthood, and childlessness) with the type of perspective partner. The first argument, which can be ascribed to opportunity motives, predicts that people belonging to similar social networks are more likely to find a partner within these circles (de Graaf \& Kalmijn, 2003). This might be the case with custodial, and to some extent, nonresident parents who attend their children's social activities, such as schools and recreational clubs (Eggebeen \& Knoester, 2001), whereas childless partners have better opportunities to meet partners without children during social activities or at work (De Graaf \& Kalmijn, 2003). Consistent with Kalmijn (1998), these pathways are expected to enhance the matching prospects of the childless with the childless and coresident parents with coresident parents.

In the second argument, preferences also play a role in shaping the type of partnership. It is reasonable to predict a pattern of homogamy for childless individuals reluctant to take on the role of stepparents. Similarly, separated parents, specifically those living with children, might be more inclined to form a union with other parents because the empathy between persons with the same parental status should favor the formation of a stepfamily where the partners both have children (Kalmijn, 1998). A competing hypothesis predicts instead that the two-parent stepfamily is less likely. Two single parents with established family routines may not find a new equilibrium as a stepfamily (Cherlin, 1978). For instance, partners' parenting styles with the mutual stepchildren may not match: the reciprocal habituation of the stepsiblings might prove problematic or the stepparent's role might prove more ambiguous if a child's biological parent is in frequent contact with the family (Hofferth $\&$ Anderson, 2003). Faced with these prospects, two potential partners will perhaps renounce living together.

Third, following the need hypothesis, repartnering with a parent who has experience in raising children may provide valuable childrearing support. Women might be relatively more averse to embark on social motherhood (caring for someone else's children) as their contribution to childrearing, which is generally higher than that of men, would perhaps prove to be time consuming in a stepfamily (Goldscheider $\&$ Sassler, 2006). Nevertheless, for the opposite reason, women might embrace stepparenthood more readily than men would because their child-care engagement is less dependent on genetic lineage (Waynforth, 2013) and because they are more tolerant than men of the family history of a potential partner (Goldscheider, Kaufman, \& Sassler, 2009). Finally, the converging goal of the transition to parenthood might promote a union between two childless individuals, whereas the same motivation would not apply to individuals who already have children (Buber \& Furnkranz-Prskawetz, 2000). The joint consideration of these three motives leads me to hypothesize that childless individuals would be more likely to repartner with other 
Table 2. Summary of Additional Mechanisms of Union Formation With a Childless Partner or a Parent, With Respect to Three Motives (Needs, Attractiveness, and Opportunity), by Parental Status

\begin{tabular}{|c|c|c|c|c|}
\hline \multicolumn{2}{|c|}{$\begin{array}{c}\text { Own parental status } \rightarrow \\
\text { New partner } \downarrow\end{array}$} & \multirow{2}{*}{$\begin{array}{c}\text { Childless person } \\
+ \text { Social activities }\end{array}$} & \multirow{2}{*}{$\begin{array}{l}\text { Nonresident parent } \\
+ \text { Pool of potential } \\
\text { partners }\end{array}$} & \multirow{2}{*}{$\frac{\text { Coresident parent }}{\text { - Social activities }}$} \\
\hline Childless partner & Opportunity & & & \\
\hline & Attractiveness & + Homogamy & $\begin{array}{l}\text { - No homogamy } \\
\text { (partly) }\end{array}$ & - No homogamy \\
\hline & Need & + Fertility intentions & & \\
\hline \multirow[t]{4}{*}{ Parent } & Opportunity & $\begin{array}{c}\text { - No access to social } \\
\text { networks of parents } \\
\text { - Pool of potential } \\
\text { partners ( } \\
\text { p mainly) }\end{array}$ & $\begin{array}{l}+ \text { Access to social } \\
\text { network of parents } \\
\text { - Pool of potential } \\
\text { partners ( }+ \text { mainly) }\end{array}$ & $\begin{array}{l}+ \text { Access to social } \\
\text { network of parents } \\
\text { - Pool of potential } \\
\text { partners ( } \\
\text { p mainly) }\end{array}$ \\
\hline & Attractiveness & - No homogamy & + Homogamy (partly) & + Homogamy \\
\hline & & $\begin{array}{l}\text { - Stepfamily } \\
\text { formation }\end{array}$ & $\begin{array}{l}\text { - Stepfamily } \\
\text { formation } \\
\text { + Propensity to } \\
\text { "social parenthood" } \\
\text { ( }+ \text { mainly) }\end{array}$ & $\begin{array}{l}\text { - Formation of a } \\
\text { complex stepfamily } \\
\text { + propensity to } \\
\text { "social parenthood" } \\
\text { (o mainly) }\end{array}$ \\
\hline & Need & & $\begin{array}{l}\text { + Childrearing } \\
\text { support (some) }\end{array}$ & $\begin{array}{l}\text { + Childrearing } \\
\text { support }\end{array}$ \\
\hline
\end{tabular}

Note. + or - indicate a mechanism that leads to an increase or a decrease in the likelihood of new union formation.

childless individuals when compared with their counterparts with dependent or nonresident children (Hypothesis 4) and that coresident and nonresident parents would be as likely as childless people to repartner with other parents (Hypothesis 5).

Few prior studies have explored the patterns of how parents or childless partners enter partnerships. Bernhardt and Goldscheider (2002) for Sweden, Goldscheider and Sassler (2006) for the United States, and Vanassche et al. (2015) for Flanders found that custodial mothers are less likely to enter union formation with childless partners (vs. no union formation) when compared with childless women. Nonresident mothers are, meanwhile, less likely to repartner than are their childless counterparts. However, empirical findings on fathers' repartnering chances are not clear, arguably because of the different specifications of children's residence. The third innovation of this study is, thus, to shed light on the existence of a systematic gender gap in repartnering among parents and childless partners on the type of a new partnership.

\section{DATA AND METHODS}

The empirical analysis is based on the Wave 1 data of Understanding Society (https://www .understandingsociety.ac.uk), a British survey that started in 2009 and 2010 with a nationally representative sample of 43,674 individuals. It collects contemporary and retrospective information on employment, partnerships, and fertility history and has a longitudinal design with annual interviews. Fertility histories are drawn from individuals' reports that recall the date of birth of each child, the possible date of departure from the household, and the reason (e.g., death, separation).

The following analyses concentrate on the life course events reported by 5,372 women and 3,375 men born between 1950 and 1979 who reported at least one relationship breakup. The analytical sample results from the exclusion of (a) 9,044 individuals who did not mention any relationship or who did not accurately recall the dates of their unions; (b) 21,218 who never separated or divorced; (c) 4,118 who were born outside the cohort range; and (d) 547 who did not match the further restrictions listed later. All singlehood spells begin in the month of union breakup and end when a new union begins or are censored: (a) when the respondent turns 50 or (b) in the month of data collection, if no union is reported. The age span is set to end at 50 because the chances of living with dependent children are very low for the separated and the divorced. I 
account only for periods of singlehood following unions that lasted 12 months or longer, regardless of their legal status, to isolate the more stable coresident unions. Furthermore, I exclude all spells of singlehood lasting fewer than 6 months to study only individuals who spend a significant period on the repartnering market. In fact, repartnering can be endogenous because the sequence of union dissolution and partner search can be reversed, with individuals deciding to interrupt their relationships after having met another partner (e.g., Ivanova et al., 2013).

Periods of singlehood following a partner's death are not analyzed. In keeping with the literature on partnership formation and dissolution (e.g., Berrington \& Diamond, 1999; Wu \& Schimmele, 2005), the relationship is considered ended when the partners' coresidence terminates and not when divorce is formalized. Accordingly, living apart together (LAT) individuals who do not coreside are not defined as cohabiting in the survey, and their postdissolution singlehood cannot be traced.

\section{Variables}

The measures of the variables are presented in Table 3, which illustrates dependent outcomes along with time-invariant and time-varying variables for partnership history, family background, year of separation, and educational achievement. Two dependent variables are used in the analysis. The first represents the formation of a partnership (either cohabitation or marriage) in a self-reported month and year $(1=$ "a new partnership"; $0=$ "singlehood"). The second defines the union start either with a childless partner $(1=$ "a new childless partner"; $0=$ "singlehood") or with a partner bringing children to the new partnership ( $1=$ "a parent as a new partner"; $0=$ "singlehood"). It is possible to detect whether the partner has some dependent children because the respondent is asked to give the birth date of her stepchildren, if any, and the period of coresidence with them for each union; no details about a partner's nonresident children are provided. Three time-varying specifications of parental status are used to test the hypotheses. First, I account for (a) the presence of at least one coresident child in the parent's household ( $1=$ "some coresident children"; $0=$ "no coresident children") and (b) the existence of some nonresident children $(1=$ "nonresident children only"; $0=$ "no nonresident children"). If both dichotomous variables equal zero, the respondent is thus childless. Understanding Society does not specify child-care time allocation, and it is possible that separated parents, and particularly fathers, who claimed full-time residence for their children actually had joint custody or other part-time arrangements in place. For this reason, the figures concerning fathers' coresident children might be partially inflated (and, similarly, those for nonresident children might be deflated). In the remaining two specifications, the following alternative indicators of the presence of coresident children are included: a four-category variable indicating the age of the youngest co-resident child ( $1=$ " $0-6$ years old"; $2=$ "7-12 years old"; $3=$ "13-18 years old"; 4 $=$ "older than 18"), and a two-category variable representing the number of coresident children ( 1 = "one child"; 2 = "two children or more").

In the analyses, I control for four characteristics of previous unions. A dummy variable identifies the previous type of union ( $1=$ "cohabitation"; $0=$ "marriage"). A previous cohabitation should imply a lower level of emotional attachment to the former partner (Nock, 1995), a lower stigma in case of dissolution, and might motivate less caution about a new union, as opposed to a previous marriage (Poortman, 2007). Another dichotomous indicator captures the number of previous unions ( $1=$ "two or more previous unions"; $0=$ "one previous union"). The first breakup could be more destabilizing than the following breakups, and a number of separations are associated with a less risk-taking attitude (Poortman, 2007) and less commitment to partnerships (Lappegård \& Rønsen, 2013). The following six time-varying splines allow for us to model duration dependency of time from the break-up: $0=$ "less than 1 year" (reference); 1 = "1-2 years"; 2= "2-4 years"; $3=$ "4-6 years"; $4=$ "6-10 years"; $\quad 5=$ " $10+$ years." Finally, a set of time-invariant spline functions indicates the duration of the previous union: $1=$ " $1-3$ years"; $2=$ " $3-5$ years"; $3=$ "5-10 years"; $4=$ " $10+$ years" (reference). I also account for the time-varying nonlinear age of the respondent, from $1=18-22$ years old to $6=41-50$ years old , to control for the age effects caused by the variable pool of eligible partners in the repartnering market (Bumpass, Sweet, \& Castro Martin, 1990). To examine trends over time in relationship instability, I control for the 
Table 3. Descriptive Statistics, by Gender and Spell of Singlehood

\begin{tabular}{|c|c|c|c|c|c|c|}
\hline \multirow[b]{3}{*}{ Variable } & \multicolumn{3}{|c|}{ Women, mean or $\%$} & \multicolumn{3}{|c|}{ Men, mean or $\%$} \\
\hline & \multicolumn{6}{|c|}{ Spell of singlehood } \\
\hline & $1 \mathrm{st}$ & 2 nd & $3 \mathrm{rd}$ & $1 \mathrm{st}$ & 2 nd & $3 \mathrm{rd}$ \\
\hline Unions with a childless partner ${ }^{\mathrm{a}}$ & 3,243 & 534 & 78 & 2,054 & 398 & 74 \\
\hline Unions with a parent ${ }^{\mathrm{a}}$ & 241 & 50 & 9 & 479 & 121 & 19 \\
\hline Childless & 31.3 & 24.6 & 24.9 & 45.2 & 36.1 & 29.8 \\
\hline Parents with nonresident children (only) & 6.8 & 12.1 & 12.4 & 27.8 & 37.9 & 48.1 \\
\hline Parents with coresident children & 61.9 & 63.8 & 63.2 & 27.0 & 26.0 & 22.1 \\
\hline \multicolumn{7}{|l|}{ By number } \\
\hline 1 & 24.7 & 25.7 & 28.5 & 15.1 & 16.1 & 14.4 \\
\hline $2+$ & 37.2 & 38.2 & 34.7 & 12.0 & 10.0 & 7.7 \\
\hline \multicolumn{7}{|l|}{ By age } \\
\hline $0-6$ & 22.1 & 16.9 & 16.6 & 11.0 & 11.2 & 7.2 \\
\hline $7-12$ & 19.2 & 20.3 & 19.7 & 8.0 & 7.3 & 5.3 \\
\hline $13-18$ & 13.2 & 17.1 & 15.5 & 5.0 & 4.6 & 8.1 \\
\hline Older than 18 & 7.2 & 9.4 & 11.4 & 2.8 & 2.8 & 1.4 \\
\hline Ever married & 66.6 & 68.4 & 74.6 & 58.2 & 53.4 & 48.6 \\
\hline Married in previous union & 66.6 & 40.2 & 30.4 & 58.2 & 27.1 & 18.5 \\
\hline With children & 53.3 & 38.0 & 27.6 & 42.1 & 23.1 & 14.4 \\
\hline Cohabiting in previous union & 33.4 & 60.4 & 70.7 & 41.8 & 73.1 & 82.2 \\
\hline With children & 15.6 & 37.8 & 48.3 & 13.4 & 35.1 & 45.6 \\
\hline Duration of previous union & 8.74 & 6.30 & 4.91 & 7.88 & 5.23 & 4.70 \\
\hline Time since union dissolution & 5.56 & 4.53 & 3.22 & 4.54 & 3.62 & 3.60 \\
\hline Age at union dissolution & 35.21 & 39.43 & 41.7 & 35.34 & 38.85 & 41.60 \\
\hline Year of separation & 1991.58 & 1996.10 & 1998.72 & 1991.84 & 1995.40 & 1997.90 \\
\hline Parents' separation & 28.0 & 36.3 & 41.0 & 26.4 & 31.9 & 35.6 \\
\hline \multicolumn{7}{|l|}{ Birth cohort } \\
\hline 1950-1954 & 12.2 & 12.0 & 10.9 & 13.8 & 12.3 & 12.5 \\
\hline $1955-1959$ & 15.1 & 14.6 & 14.5 & 16.9 & 16.5 & 16.8 \\
\hline $1960-1964$ & 20.0 & 21.4 & 24.4 & 20.1 & 23.7 & 25.5 \\
\hline 1965-1969 & 20.4 & 23.2 & 24.9 & 22.0 & 24.3 & 23.1 \\
\hline 1970-1974 & 18.6 & 19.5 & 23.8 & 16.4 & 15.7 & 15.9 \\
\hline 1975-1979 & 13.4 & 9.2 & 15.5 & 19.7 & 7.5 & 6.3 \\
\hline \multicolumn{7}{|l|}{ Ethnicity } \\
\hline European & 88.0 & 91.9 & 95.9 & 89.6 & 90.8 & 92.3 \\
\hline African-Caribbean & 6.6 & 5.4 & 3.1 & 5.3 & 6.2 & 5.2 \\
\hline Indian, Pakistani, Bangladeshi & 2.9 & 1.1 & 0 & 3.1 & 1.4 & 1.0 \\
\hline South-East Asia & 1.1 & 0.7 & 0.5 & 0.5 & 0.1 & 0 \\
\hline Other & 1.3 & 0.8 & 0.5 & 1.3 & 1.3 & 1.4 \\
\hline \multicolumn{7}{|l|}{ Education } \\
\hline ISCED 0-1-2 & 35.2 & 34.8 & 33.7 & 35.1 & 33.2 & 36.5 \\
\hline ISCED 3-4 & 51.9 & 53.9 & 57.0 & 54.4 & 57.6 & 55.8 \\
\hline ISCED 5-6-7 & 12.9 & 11.3 & 9.3 & 10.5 & 9.2 & 7.7 \\
\hline Father has a job & 84.5 & 82.9 & 80.8 & 86.7 & 84.1 & 80.3 \\
\hline$n$ & 5,372 & 1,196 & 193 & 3,375 & 828 & 208 \\
\hline Person-periods & 61,269 & 11,653 & 1,398 & 31,615 & 6,499 & 1,668 \\
\hline
\end{tabular}

Note. Source is Wave 1 of Understanding Society. Spells from $4^{\text {th }}$ onwards are not shown. Means are calculated over persons, not person-periods, and per spell, unless otherwise stated, and are computed in the last month of each singlehood spell, except for age at union dissolution. Means for these time-varying variables are calculated in years refer to the last 6-month episode of the spell. ISCED = International Standard Classification of Education.

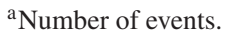


logarithm of the year of separation (continuous variable, range: 1966-2010) such as in de Graaf and Kalmijn (2003). Research on the intergenerational association of family structure implies that individuals' union instability may echo their own childhood family disruptions (Amato, 1996; Liefbroer \& Elzinga, 2012), parents' interpersonal problems (Axinn \& Thornton, 1996), or economic hardship (Kiernan, 1992). For this purpose, I use a dummy variable indicating whether parents were still a couple when the respondent was aged $16(1=$ "parents' dissolution"; $0=$ "intact family") and one indicator for whether the father was employed at the same age $(1=$ "father had a job"; $0=$ "father was unemployed"). Finally, higher education positively influences either first partnership formation (e.g., Winkler-Dworak \& Toulemon, 2007) or repartnering (e.g., Ivanova et al., 2013; Stewart, Manning, \& Smock, 2003) due to greater attractiveness in the marriage market (Kaufman, 2000) and to better social integration (e.g., de Graaf \& Kalmijn, 2003). Educational levels are measured by the cross-nationally comparable International Standard Classification of Education (ISCED; United Nations Educational, Scientific and Cultural Organization, 2011): $1=$ "ISCED 0-1-2" (less than or equal to lower secondary education); $2=$ "ISCED 3-4" (upper and post-secondary education); $3=$ "ISCED 5-6-7" (tertiary education and higher, reference). Eventually, a five-category time invariant variable captures a respondent's self-reported ethnicity: $1=$ "European" (reference); 2 = "African-Caribbean"; 3 = "Indian, Pakistani, Bangladeshi"; 4 = "South-East Asian"; 5 = "other ethnicity."

\section{Analytical Strategy}

The empirical strategy draws on the models developed by Steele $(2008,2011)$ for multilevel discrete-time event-history models for competing risks. This approach brings some major advantages. First, it makes possible the inclusion of repeated events rather than first-order transitions. Related to this, it can identify the influence of previous partnerships on new unions and helps disentangle the role of prior children from that of past partnerships. Furthermore, it explicitly accounts for the individuals' unobserved heterogeneity-he or she has attractive personality traits or prefers a partnership to singlehood-which may lead to unstable relationships and multiple partnership entries. Therefore, the duration of the episodes for each respondent could be correlated with one another through the unobserved heterogeneity component (or frailty). The inclusion of this component in the analytical model corrects for episode dependency and tests the assumption made in standard methods that all durations must be independently distributed (Steele, 2011). The traditional nonfrailty models are also performed as robustness checks and used to better identify the interplay of the individual-level component and its covariates.

The repartnering process is modelled as a sequence of singlehood episodes in which individuals risk entry into a new union. For each episode of singlehood, I construct a person per 6-month file containing time-varying and invariant information about the individual because the person-month data set-although possible - is mathematically challenging for the software. Any spell starts in the semester of the last union dissolution and ends with the formation of a new union or with a censored spell for those who have not experienced the event by the end of the observation period. All episodes of singlehood are nested within each individual, which yields a two-level data structure. The multilevel (or random effect) event history models adopted in this study were purposely developed for a hierarchical data structure (Steele, 2011).

Two models are tested. The first addresses the risk of entry into a union; the second, a competing risk model, addresses the risks of transition from singlehood to a new union with (a) a childless partner (vs. staying single) or (b) with a partner bringing children (vs. staying single), and employs two binary response models. No direct transition from state (a) to (b) occurs in the sample and is, thus, modelled in the analyses. The hazard of making a transition to the new state can be defined as a two-level random effects logistic model:

$$
h_{i j t}=\log \left(\frac{p_{i j t}^{(r)}}{1-p_{i j t}^{(r)}}\right)
$$

where $r(r=1)$ in the first model, and $r(r=1,2)$ in the second model and $p^{(r)}{ }_{i j t}$ is the probability that a transition $r$ occurs at time $t$ during episode $j$ for the individual $i$.

$$
h_{i j t}=\alpha_{i j}^{(r)}(t)+\beta_{i j} \boldsymbol{X}_{i j t}^{(r)}+\gamma_{i} \boldsymbol{W}_{i}^{(r)}+u_{i}^{(r)}
$$


where $\alpha_{i j}{ }^{(r)}(t)$ is a function of time and consists of linear splines capturing the duration of the single status after union dissolution; $\boldsymbol{X}_{i j t}{ }^{(r)}$ and $\boldsymbol{W}_{i}{ }^{(r)}$ are vectors of time-varying and invariant covariates with, respectively, coefficients $\beta_{i j}$ and $\gamma_{i} ; u_{i}^{(r)}$ capture individuals' random effects and are assumed to follow a normal distribution with zero mean and variance $\sigma^{2}$. The model assumes that, conditional on $u_{i}$, the duration of episodes for the same individual are independent. I present models for distinct samples of men and women in Tables 4-6 and pooled models of men and women to highlight key differences in parental status by gender in Figures 1 and 2 .

The competing risk model is computationally demanding and is estimated with Markov Chain Monte-Carlo methods with the MLwiN package runmlwin for Stata 13 (Leckie \& Charlton, 2012). The starting values of coefficients are derived from the iterative generalized least squares algorithm. The Markov Chain Monte-Carlo estimation includes a burn-in of 10,000 iterations, followed by a monitoring period of 100,000 iterations. In addition, I apply parameter expansion to improve convergence.

Although the multilevel approach brings clear advantages, the interpretation of the results requires that certain limitations be considered. First, the model does not allow for unobservable time-varying characteristics. Therefore, it must be assumed that, for instance, individuals' predisposition to relationship hopping and attractiveness is stable over time. Second, although the estimation of individual-level heterogeneity tackles possible self-selection on unmeasured characteristics associated with multiple union entries and exits, the coefficients should still be read as associations rather than causal effects. For instance, the presence of coresident children is not exogenous with respect to repartnering. Indeed, it is possible that single parents selectively choose to live without children to enhance their chances on the repartnering market.

\section{RESULTS}

Model 1 in Table 4 (women) and Table 5 (men) presented the effect of children's residence status on parents' chances of forming a new partnership, with childless individuals as the reference category. The results are presented as odds ratios, which represent the relative likelihood of someone with given characteristics entering a union when compared with someone who remains single.

The presence of coresident children in the household was associated with less frequent repartnering for mothers (about 40\% lower) when compared with their childless counterparts and to nonresident mothers. It did not, though, decrease the chances of new partnerships for men. These findings supported the idea that the combined mechanisms of attractiveness, need, and opportunities ultimately hamper the repartnering chances of custodial parents differently by gender.

Models 2 and 3 addressed how new union formation was conditioned by child-care burdens, which was proxied by the age of the youngest coresident child and by the number of dependent children. Mothers' repartnering odds were sizeably reduced in the earlier stages of a child's life and picked up slightly as the child grew, but they remained significantly lower than for childless women and nonresident mothers. This negative "child age gradient" on new union odds did not emerge from the analysis of fathers. The odds for custodial fathers with dependent children aged 0 to 6 were comparable with those of childless men and even decreased as the child aged. The other indicator of child-care burden confirmed the hypothesis that the number of children influenced parents' repartnering. Mothers' odds appeared to be coherent with the hypothesis that raising two or more children was more burdensome than raising one child (the coefficients were statistically different at the 95\% level), whereas the likelihood of repartnering with coresident fathers did not significantly change according to the number of dependent children. A number of robustness checks (i.e., modifying the age range, the time windows of the previous unions, and the time elapsed since the dissolution) did not show relevant changes.

The influence of a previous partnership history was measured in terms of experience of cohabitation (vs. marriage) in the previous union, the number of previous unions, and the length of the previous partnership. Among these, only the last seemed to matter for men and women, as the chances of repartnering increased significantly after exiting longer relationships. The time elapsed since the end of the previous union had a nonlinear effect on repartnering, with men's chances falling steeply after 6 years and women's after 1 year. Repartnering probabilities were essentially 
Table 4. Effects of Characteristics of Parenthood Status on New Union Formation: Women

\begin{tabular}{|c|c|c|c|c|c|c|}
\hline \multirow[b]{2}{*}{ Variables } & \multicolumn{2}{|c|}{ Model 1} & \multicolumn{2}{|c|}{ Model 2} & \multicolumn{2}{|c|}{ Model 3} \\
\hline & $O R$ & $S E B$ & $O R$ & $S E B$ & OR & $S E B$ \\
\hline \multicolumn{7}{|l|}{ No children (ref.) } \\
\hline Nonresident only & 1.02 & 0.08 & 1.01 & 0.08 & 1.14 & 0.1 \\
\hline Some coresident & $0.60^{* * *}$ & 0.03 & & & & \\
\hline \multicolumn{7}{|l|}{ \# Coresident } \\
\hline 1 child & & & $0.64^{* * *}$ & 0.03 & & \\
\hline $2+$ children & & & $0.56^{* * *}$ & 0.03 & & \\
\hline \multicolumn{7}{|l|}{ Youngest coresident } \\
\hline 0-6 years & & & & & $0.58^{* * * *}$ & 0.03 \\
\hline $7-12$ years & & & & & $0.63^{* * *}$ & 0.04 \\
\hline $13-18$ years & & & & & $0.75^{* * *}$ & 0.05 \\
\hline Older than 18 years & & & & & $0.81^{* *}$ & 0.08 \\
\hline Previous cohabitating & 1.05 & 0.05 & 1.04 & 0.05 & 1.03 & 0.05 \\
\hline $2+$ previous unions & 0.99 & 0.06 & 0.99 & 0.06 & 1.00 & 0.06 \\
\hline \multicolumn{7}{|c|}{ Time since dissolution (ref.: $0.5-1$ years) } \\
\hline $1-2$ years & $0.91^{*}$ & 0.05 & $0.92^{*}$ & 0.05 & $0.91^{*}$ & 0.05 \\
\hline $2-4$ years & 0.93 & 0.05 & 0.93 & 0.05 & 0.91 & 0.05 \\
\hline $4-6$ years & 0.89 & 0.07 & 0.90 & 0.07 & $0.86^{* *}$ & 0.07 \\
\hline $6-10$ years & $0.78^{* *}$ & 0.08 & $0.79^{* *}$ & 0.08 & $0.73^{* * * *}$ & 0.07 \\
\hline Older than 10 years & $0.66^{* * *}$ & 0.09 & $0.67^{* * *}$ & 0.09 & $0.59^{* * *}$ & 0.08 \\
\hline \multicolumn{7}{|c|}{ Duration of last union (ref.: $10+$ years) } \\
\hline $1-3$ years & $0.70^{* * *}$ & 0.05 & $0.69^{* * *}$ & 0.05 & $0.73^{* * *}$ & 0.05 \\
\hline $3-5$ years & $0.82^{* * *}$ & 0.05 & $0.80^{* * *}$ & 0.05 & $0.85^{* * *}$ & 0.05 \\
\hline $5-10$ years & $0.75^{* * *}$ & 0.04 & $0.74^{* * *}$ & 0.04 & $0.78^{* * *}$ & 0.05 \\
\hline \multicolumn{7}{|l|}{ Age (ref.: $18-22$ years) } \\
\hline 23-26 years & $1.18^{*}$ & 0.11 & $1.19^{* *}$ & 0.11 & $1.18^{*}$ & 0.11 \\
\hline $27-30$ years & 1.17 & 0.12 & $1.19^{*}$ & 0.11 & 1.17 & 0.12 \\
\hline $31-35$ years & 0.91 & 0.10 & 0.93 & 0.11 & 0.90 & 0.10 \\
\hline $36-42$ years & $0.68^{* * *}$ & 0.09 & $0.69^{* * *}$ & 0.09 & $0.64^{* * * *}$ & 0.09 \\
\hline $43-50$ years & $0.39^{* * *}$ & 0.06 & $0.40^{* * *}$ & 0.06 & $0.36^{* * *}$ & 0.06 \\
\hline \multicolumn{7}{|c|}{ Education (ref.: ISCED 5-6-7) } \\
\hline ISCED 3-4 & 1.02 & 0.04 & 1.02 & 0.04 & 1.01 & 0.05 \\
\hline ISCED 0-1-2 & $0.77^{* * *}$ & 0.05 & $0.78^{* * *}$ & 0.05 & $0.77^{* * *}$ & 0.04 \\
\hline$\rho$ & \multicolumn{2}{|c|}{0.09} & \multicolumn{2}{|c|}{0.09} & \multicolumn{2}{|c|}{0.08} \\
\hline$\chi^{2}$ & \multicolumn{2}{|c|}{1,355} & \multicolumn{2}{|c|}{1,354} & \multicolumn{2}{|c|}{1,417} \\
\hline$n$ & \multicolumn{2}{|c|}{5,372} & \multicolumn{2}{|c|}{5,372} & \multicolumn{2}{|c|}{5,372} \\
\hline Persons-periods & \multicolumn{2}{|c|}{74,763} & \multicolumn{2}{|c|}{74,763} & \multicolumn{2}{|c|}{74,763} \\
\hline
\end{tabular}

Note. Additional controls: whether parents separated by age 16, year of separation log, ethnicity, and employed father when the individual was 16. ISCED = International Standard Classification of Education; ref. = reference.

${ }^{* * *} p<.01 ;{ }^{* *} p<.05 ;{ }^{*} p<.1$.

flat from age 18 through 35 and decreased sharply thereafter. Those with little education were severely disadvantaged when compared with those who had a degree. Among family background characteristics, parents' partnership stability was positively associated only with men's new union formation, and this held true, too, for the father's employment.
Finally, unobserved heterogeneity played a role. The total variance explained by individual frailty ranged from about $6 \%$ to $9 \%$ and was significantly different from zero. The alternative models without the individual-level component (not shown) presented lower odds ratios for the splines of singlehood time and slightly higher odds ratios for the proxies 
Table 5. Effects of Characteristics of Parenthood Status on New Union Formation: Men

\begin{tabular}{|c|c|c|c|c|c|c|}
\hline \multirow[b]{2}{*}{ Variables } & \multicolumn{2}{|c|}{ Model 1} & \multicolumn{2}{|c|}{ Model 2} & \multicolumn{2}{|c|}{ Model 3} \\
\hline & $O R$ & $S E B$ & OR & $S E B$ & $O R$ & $S E B$ \\
\hline \multicolumn{7}{|l|}{ No children (ref.) } \\
\hline Nonresident only & 1.07 & 0.06 & 1.07 & 0.06 & 1.06 & 0.06 \\
\hline Some coresident & 0.93 & 0.05 & & & & \\
\hline \multicolumn{7}{|l|}{ \# Coresident } \\
\hline 1 child & & & 0.94 & 0.06 & & \\
\hline $2+$ children & & & 0.93 & 0.07 & & \\
\hline \multicolumn{7}{|l|}{ Youngest coresident } \\
\hline $0-6$ years & & & & & 0.95 & 0.06 \\
\hline $7-12$ years & & & & & 0.97 & 0.07 \\
\hline $13-18$ years & & & & & $0.78^{*}$ & 0.07 \\
\hline Older than 18 years & & & & & $0.73^{*}$ & 0.11 \\
\hline Previous cohabitating & 1.08 & 0.06 & 1.08 & 0.06 & 1.08 & 0.05 \\
\hline $2+$ previous unions & 1.01 & 0.06 & 1.01 & 0.07 & 1.01 & 0.06 \\
\hline \multicolumn{7}{|c|}{ Time since dissolution (ref.: $0.5-1$ years) } \\
\hline $1-2$ years & 0.92 & 0.06 & 0.92 & 0.06 & 0.93 & 0.05 \\
\hline $2-4$ years & 0.92 & 0.07 & 0.92 & 0.07 & 0.92 & 0.06 \\
\hline $4-6$ years & 0.92 & 0.09 & 0.92 & 0.09 & 0.93 & 0.09 \\
\hline $6-10$ years & $0.74^{* *}$ & 0.09 & $0.74^{* *}$ & 0.09 & $0.74^{* *}$ & 0.09 \\
\hline Older than 10 years & $0.73^{*}$ & 0.12 & $0.73^{*}$ & 0.12 & 0.74 & 0.12 \\
\hline \multicolumn{7}{|c|}{ Duration of last union (ref.: $10+$ years) } \\
\hline $1-3$ years & $0.63^{* * *}$ & 0.05 & $0.63^{* * *}$ & 0.05 & $0.62^{* * *}$ & 0.05 \\
\hline $3-5$ years & $0.64^{* * *}$ & 0.05 & $0.63^{* * *}$ & 0.05 & $0.62^{* * *}$ & 0.04 \\
\hline $5-10$ years & $0.68^{* * * *}$ & 0.05 & $0.68^{* * * *}$ & 0.05 & $0.66^{* * *}$ & 0.05 \\
\hline \multicolumn{7}{|l|}{ Age (ref.: $18-22$ years) } \\
\hline $23-26$ years & $1.24^{*}$ & 0.17 & $1.24^{*}$ & 0.17 & $1.42^{*}$ & 0.16 \\
\hline $27-30$ years & $1.25^{*}$ & 0.18 & $1.25^{*}$ & 0.18 & $1.24^{*}$ & 0.17 \\
\hline $31-35$ years & 0.98 & 0.16 & 0.98 & 0.16 & 0.98 & 0.16 \\
\hline $36-42$ years & $0.71^{* *}$ & 0.15 & $0.71^{* *}$ & 0.15 & $0.71^{* *}$ & 0.14 \\
\hline $43-50$ years & $0.40^{* * *}$ & 0.10 & $0.40^{* * *}$ & 0.10 & $0.41^{* * *}$ & 0.10 \\
\hline \multicolumn{7}{|c|}{ Education (ref.: ISCED 5-6-7) } \\
\hline ISCED 3-4 & 0.94 & 0.04 & 0.94 & 0.04 & 0.94 & 0.05 \\
\hline ISCED 0-1-2 & $0.66^{* * *}$ & 0.06 & $0.66^{* * *}$ & 0.06 & $0.66^{* * *}$ & 0.04 \\
\hline$\rho$ & \multicolumn{2}{|c|}{0.06} & \multicolumn{2}{|c|}{0.07} & \multicolumn{2}{|c|}{0.07} \\
\hline$\chi^{2}$ & \multicolumn{2}{|c|}{497} & \multicolumn{2}{|c|}{496} & \multicolumn{2}{|c|}{505} \\
\hline$b$ & \multicolumn{2}{|c|}{3,375} & \multicolumn{2}{|c|}{3,375} & \multicolumn{2}{|c|}{3,375} \\
\hline Persons-periods & \multicolumn{2}{|c|}{40,095} & \multicolumn{2}{|c|}{40,095} & \multicolumn{2}{|c|}{40,095} \\
\hline
\end{tabular}

Note. Additional controls: whether parents separated by age 16, year of separation log, thnicity. and e mployed father when

the individual was 16 . ISCED = International $\mathrm{S}$ logarithm of year of separation ivin, ret. = reference.

${ }^{* * *} p<.01 ;{ }^{* *} p<.05 ;{ }^{*} p<.1$.

ethnicity, and employed father

of custodial parenthood. Unobserved heterogeneity was thus negatively associated with the duration dependence of repartnering and positively associated with coresident parenthood. This implied that people with children possessed traits such as family-oriented values that increased the likelihood of union formation.
Pooling men and women in the same model and interacting gender with the other covariates helped me identify how the association between parental status and new union formation differed between men and women. At first glance, Figure 1 highlights a significant imbalance between genders in terms of repartnering. Fathers' chances of 
Table 6. Competing Risks Model: Effects of Characteristics of Parenthood Status on New Union Formation by Type of Partner, Odds Ratios

\begin{tabular}{|c|c|c|c|c|}
\hline \multirow[b]{3}{*}{ Variables } & \multicolumn{2}{|c|}{ Women } & \multicolumn{2}{|c|}{ Men } \\
\hline & Partner without children & Partner with children & Partner without childreı & Partner with children \\
\hline & \multicolumn{2}{|c|}{ Model 4} & \multicolumn{2}{|c|}{ Model 5} \\
\hline \multicolumn{5}{|l|}{ No. children (ref. = 1) } \\
\hline Nonresident children (only) & 0.99 & 1.18 & 1.12 & $1.32^{* * *}$ \\
\hline Some coresident children & $0.57^{* * * *}$ & 1.06 & $0.85^{* * *}$ & $1.22^{*}$ \\
\hline$n$ & \multicolumn{2}{|c|}{5,372} & \multicolumn{2}{|c|}{3,375} \\
\hline Persons-periods & \multicolumn{2}{|c|}{74,763} & \multicolumn{2}{|c|}{40,095} \\
\hline
\end{tabular}

Note. Separate samples of men and women. Additional controls: any previous marriage (dummy), more than one previous union, time since union dissolution, length of previous union, fumily status at age 16, logarithm of year of separation, age, ethnicity, education, father employed when respon ent is 16 . ref. $=$ reference.

${ }^{* * *} p<.01 ;{ }^{* *} p<.05 ;{ }^{*} p<.10$.

16 , ref. $=$ reference

Figure i. Probability of a New Union by Parental Status, Number, and Age of Children.

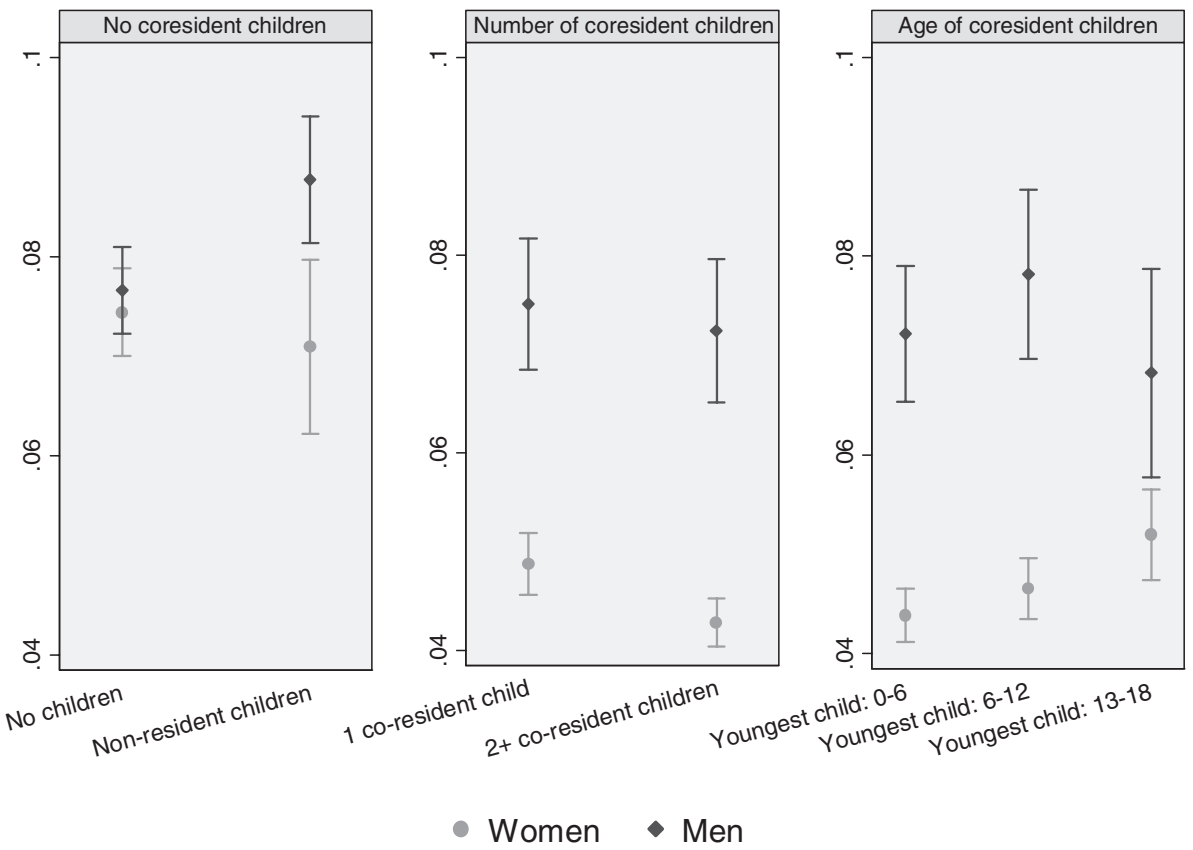

Note. Average predicted probability in each 6-month episode. Pooled sample of men and women.

finding a new partner remained steadily above those of mothers, regardless of children's residence status, number, and age. Only the repartnering probabilities of childless men and women did not differ significantly. Assuming that the number of children and their age were good proxies for the child-care burden and that these affected custodial mothers and fathers to a similar extent, the findings clearly revealed gender-driven mechanisms of repartnering. However, it was not possible to test exhaustively whether it was the attractiveness hypothesis, the need hypothesis, or both that explained the gap between custodial fathers and mothers.

Table 6 illustrates the results of the competing risk model of union formation with a childless or a parent partner. Models are 
Figure 2. Probability of a New Union With a Childless Partner or a Parent With Coresident Children by Parental Status.

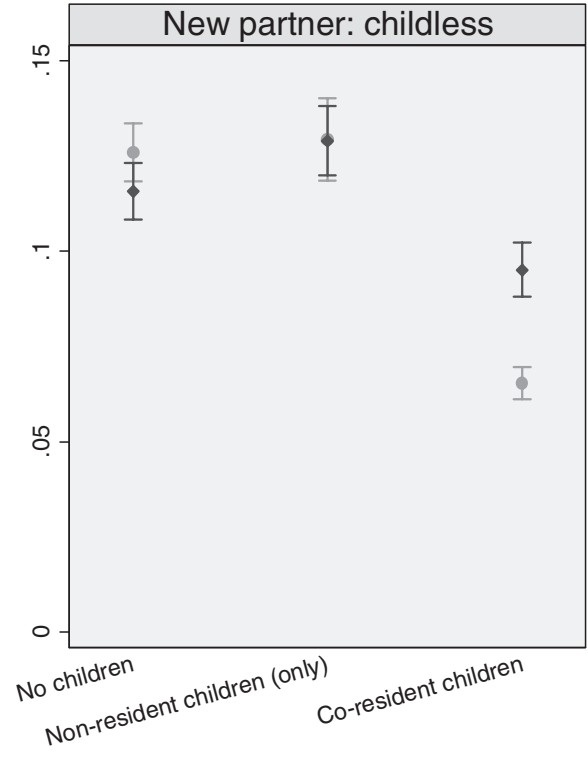

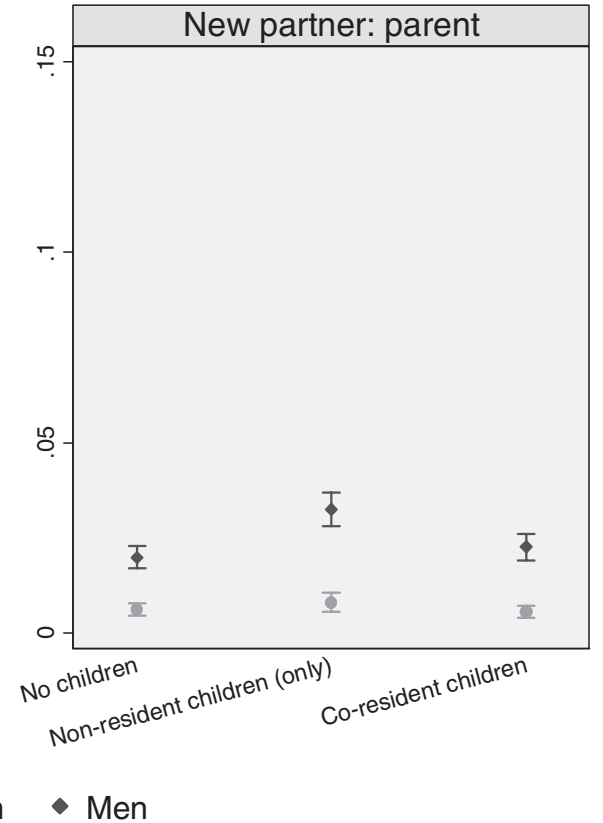

Note. Average predicted probability in each 6-month episode. Pooled sample of men and women.

presented for women and men, separately. The results are presented as odds ratios and represent the relative risk of an individual with determined characteristics entering a specific union (with a childless partner or with a person with coresident children) compared to remaining single. Both men and women with dependent children were less likely to enter a union with partners without children (vs. remaining single) when compared with childless individuals.

Conversely, custodial mothers were as likely as their childless counterparts to enter a union with other parents, and fathers were marginally more likely to do so. The combination of these results highlighted a partner selection mechanism. Custodial parents' lack of attractiveness within the pool of childless people could be made up for by assortative mating mechanisms between single parents. Fathers with nonresident children were significantly more likely to repartner with a parent (vs. remaining single), but not to form unions with childless partners (vs. remaining single), at least with respect to the childless. Nonresident mothers, instead, did not systematically differ from childless women in repartnering. These outcomes suggested that child custody, rather than parenthood per se, lowered parents' risks of new union formation with a childless partner and that potential childless partners could not be motivated to embrace the role of stepparents.

Figure 2 shows women and men's probabilities of repartnering with childless partners and with coresident parents in the following three different parental conditions: childlessness, nonresident parenthood, and coresident parenthood. Distinct "intergender" behaviors of conjugal reconstruction emerged. Childless women and men did not have significantly different repartnering probabilities with other childless partners. However, the condition of custodial parent implied a distinct gap between mothers and fathers in terms of repartnering with nonparents. Furthermore, a gender imbalance showed up in repartnering probabilities with a coresident parent for all three parental conditions. Men were significantly more likely to enter unions with parent partners than were women. 
These findings did not support the argument that men opted out of stepparenthood more than women. Conversely, the evidence suggested that the relatively higher probability that men would partner with parents, when compared with women, could also be driven by the larger availability of separated custodial mothers. In conclusion, these results did not support either the hypothesis of women's greater willingness to care for someone else's children or men's supposedly greater resistance to embarking on stepparenthood, as hypothesized by Bernhardt and Goldscheider (2002).

\section{DISCUSSION}

This study examined the determinants of new union formation and the competing risks of entering a union with a childless partner and with a partner who has children. Few studies have taken together the role of children and potential partners in new relationships. This article improves on previous work by offering, through an innovative methodology, an intergender analysis for Britain, including people's full partnership history.

I tested the hypothesis that the presence of coresident children is negatively associated with new union formation and particularly with entering a union with a childless partner. I also predicted that parental responsibilities might be associated with a gender gap in terms of men and women's new union prospects and influenced different transitions to coresident stepparenthood. The results partially confirm these hypotheses. In the first part of the study, I find that only coresident mothers repartner at a lower rate than do their childless counterparts, whereas fathers do not. This evidence deviates from previous studies showing that fathers with custody are not quicker to repartner than other men (in contrast with Goldscheider \& Sassler, 2006) and that the gender differences in repartnering are significant even when their parenthood status is considered (in contrast with Ivanova et al., 2013). Furthermore, the parental child-care burden-proxied by children's age and number-has a negative influence on mothers' repartnering prospects, but not on fathers'. The material limitations associated with the presence of children, which reduce parents' time for meeting potential partners and for forming new relationships, might explain the gap between custodial mothers and childless women, but these limitations do not untangle the gender gap between custodial parents.

Assuming that childrearing constraints are the same for single mothers as for fathers, this gap can be partly explained by the combination of custodial fathers' relatively greater attractiveness or by their more proactive partner search or, indeed, by both. In this respect, the "good-father" hypothesis might be justified by the very specific sociodemographic profile of custodial fathers (Haux et al., 2016), who perhaps appear more dependable to partners (Lappegård, \& Rønsen, 2013). Also, childbearing expectations for the new union may differently shape the repartnering behavior of men and women. Fathers are able to have children at older ages and may thus be in less of a hurry in their quest for a new conjugal experience. By contrast, mothers who are still in their childbearing years may look for a partner to have children with, but they may also renounce childbearing as their reproductive cycle ends earlier. Finally, some studies have also stressed that women may be more susceptible to the demise of a relationship (e.g., Poortman, 2007) and that they tend to disengage from romantic life in the aftermath of a failure (Beaujouan, 2012). The presence of children could be a further reason to renounce a new partnership so as to avoid interference in an established child-care routine. Other studies have attributed this gender gap to age-dependent behavior and to partners' availability, as women's partnership formation decreases at the beginning of their early 30s, relative to men (Beaujouan, 2012). Additional research focusing on age-specific repartnering behavior, an issue not addressed in this study, might shed some more light on gender differences.

Similarly to the findings of Ivanova et al. (2013), the repartnering of noncustodial parents proceeds at the same pace as that of childless individuals regardless of gender. Two explanations seem plausible and they are not necessarily mutually exclusive. It could be that nonresident parents, freed from child-custody burdens, behave similarly to childless individuals ("constraint hypothesis"). Also, it is possible that nonresident parents face some constraints that impair their union prospects (such as duties with their absent children and potential partners' scepticism about their previous relationships) 
and that they compensate for this by seeking a partner to make up for their children's absence.

The pooled model also highlights a gap between nonresident fathers and mothers. However, the interpretation of this divide has to account for the different profiles of the two groups. The overwhelming majority of fathers do not retain child custody and they are heterogeneous in many domains (e.g., Haux, et al., 2015; Poole et al., 2015). Women who live apart from their children are rarer and generally represent two very distinct conditions: those who voluntarily relinquish child custody to guarantee their environmental stability, for instance, after leaving the household to live with a new partner; and those who are involuntarily removed from parental tasks, having lost custody rights via a court decision or because the children themselves refuse contact (Kielty, 2006). Those who voluntarily give up on child custody might be expected to trigger separation and to more rapidly set up a new union when they find a new partner (Beaujouan, 2012), whereas those who have involuntarily been cut off from their children might find that the pathway to repartnering could be impaired by troubled socioeconomic conditions (e.g., Goldscheider \& Sassler, 2006). Therefore, the sample exclusion of individuals who repartner within 6 months of their union dissolution-which might rule out most women from the first group - could partly explain the repartnering gap between nonresident mothers and fathers.

The second part of the analyses highlights how custodial responsibilities also shape the type of new union. In general, custodial children are a deterrent to potential unions with childless partners, but not with other parents: Coresident mothers are not less likely to repartner with other parents and custodial fathers have marginally higher odds of repartnering with other parents when compared with their childless counterparts. The following mechanisms might shed light on these results. First, coresident parents may prove more attractive to other parents than they are to childless men and women because of partnership homogamy, as also shown by Vanassche et al. (2015). Second, childless men and women might be unwilling to embrace stepparenthood, a challenging trial when it comes to role definition within the couple and relationship build-up with nonbiological children.
The idea that custodial parenthood-and not parenthood per se-is unattractive in the repartnering market is also borne out by the intergender comparison of probabilities for a new union. Women's coresident children reduce the odds of repartnering with childless partners to a larger extent than men, whereas the few women who do not retain child custody are as likely to enter new unions with childless partners as are noncustodial fathers. A gender gap in the probability of a new union with a parent emerges clearly: Men's chances are notably greater than women's regardless of their parental status. A plausible explanation may lie in the prevalence of custodial mothers (vs. fathers) among potential partners on the remarriage market, as hypothesized by Bernhardt and Goldscheider (2002).

This study has some limitations. First, the nature of child custody is not exogenous to parental characteristics; some parents, for instance, may purposely reject their parental responsibilities to enhance their chances of repartnering. Furthermore, the data have not allowed me to measure the proportion of time separated parents devote to their children. The descriptive statistics suggest that fathers with part-time custody sometimes claim to have full child-care responsibility. This measurement error could inflate the rate of repartnering of custodial fathers, some of whom may only have part-time arrangements. Finally, I did not address the influence of parental status on whether individual choose cohabitation or marriage: The sample size was insufficient. Future research addressing this repartnering mechanism might shed more light on key issues such as partnership stability and family functioning among newly established couples and stepfamilies.

Despite these data shortcomings, the repartnering gap finds further empirical support in this analysis of British data. This divide is explained by mothers' lower repartnering rates, both with childless partners and with parents when compared with other women and men and is further shown by the greater number of women among custodial parents. More gender-egalitarian provisions in child custody could help balance out the realities faced by separated parents and ultimately ease mothers' new union formation.

Recent British research suggests that the 50\% and $50 \%$ custody division represents a very 
small share of custody arrangements, whereas a $65 \%$ and $35 \%$ division is more common, be it among those who separated on friendly terms or through judicial procedure (Trinder, 2010). This arrangement is not formalized by any specific legislative provision, although the government has undertaken some concrete steps to expand its use (The Ministry of Justice \& Department for Education, 2012), and the Children and Families Act (2014, p. 11) has formally replaced the dichotomy "residence order" versus "contact order" to identify, respectively, the custody holder and the other parent with a more neutral "child arrangements order" (Harding \& Newnham, 2015). Growing evidence about repartnering, including this study, suggests the need for gender-equal policies in postseparation child arrangements.

\section{Note}

I thank Gøsta Esping-Andersen, Roberta Rutigliano, Léa Pessin, Bruno Arpino, Nicoletta Balbo, Katya Ivanova, and Valeria Cetorelli for their helpful comments on earlier versions of this article. The research was supported by the European Research Council (Grant 269387 - "Stratified Family Dynamics") and by the Ministry of Economy and Competition of Spain (Grant CSO2013-43461-R).

\section{SUPPORTING INFORMATION}

Additional supporting information may be found online in the Supporting Information section at the end of the article.

Appendix S1. Robustness check. Alternative version of Tables $3 \& 4$. Sample including people exiting all unions (also shorter than 12 months) and experiencing at least 1-month singlehood episodes.

Robustness check. Alternative version of Table 5. Sample including people exiting all unions (also shorter than 12 months) and experiencing at least 1-month singlehood episodes.

\section{REFERENCES}

Allison, P. D. (1982). Discrete-time methods for the analysis of event histories. Sociological Methodology, 13, 61-98.

Amato, P. R. (1996). Explaining the intergenerational transmission of divorce. Journal of Marriage and the Family, 58, 628-640. https://doi.org/10.2307/ 353723

Amato, P. R., \& Kane, J. B. (2011). Life-course pathways and the psychosocial adjustment of young adult women. Journal of Marriage and Family, 73, 279-295. https://doi.org/10.1111/j.1741-3737 $.2010 .00804 . x$
Axinn, W. G., \& Thornton, A. (1996). The influence of parents' martial dissolutions on children's attitudes toward family formation. Demography, 33(1), 66-81. https://doi.org/10.2307/2061714

Beaujouan, É. (2012). Repartnering in France: The role of gender, age and past fertility. Advances in Life Course Research, 17(2), 69-80. https://doi .org/10.1016/j.alcr.2012.03.001

Beaujouan, É., \& Ní Bhrolcháin, M. (2011). Cohabitation and marriage in Britain since the 1970s. Population Trends, 145, 31-55. https://doi.org/10.1057/ pt.2011.16

Becker, G. S. (1981). A treatise on the family. Cambridge: Harvard University Press.

Bernhardt, E., \& Goldscheider, F. (2002). Children and union formation in Sweden. European Sociological Review, 18(3), 289-299. https://doi.org/10 .1093/esr/18.3.289

Berrington, A., \& Diamond, I. (1999). Marital dissolution among the 1958 British birth cohort: The role of cohabitation. Population Studies, 53(1), 19-38. https://doi.org/10.1080/00324720308066

Berrington, A., \& Stone, J. (2017). Understanding third and fourth births in Britain: What role do increased immigration and multiple partnerships play? (Working Paper No. 83). ESRC Centre for Population Change.

Blackwell, A., \& Dawe, F. (2003). Non-resident parental contact (Omnibus Survey Report 38). London: Office of National Statistics.

Boertien, D. (2016, April). Have our relationships become more stable? Investigating trends in union stability and its consequences for theories on couple behavior. Paper presented at Population Association of America Annual Meeting 2016, Washington, DC.

Bradshaw, J., \& Miller, J. (1991). Lone parent families in the UK (Department of Social Security Research Report No. 6). London, UK: HMSO.

Brown, S. L., \& Manning, W. D. (2009). Family boundary ambiguity and the measurement of family structure: The significance of cohabitation. Demography, 46(1), 85-101. https://doi.org/ 10.1353/dem.0.0043

Buber, I., \& Furnkranz-Prskawetz, A. (2000). Fertility in second unions in Austria: Findings from the Austrian FFS. Demographic Research, 3. https:// doi.org/10.4054/DemRes.2000.3.2

Bumpass, L., Sweet, J., \& Castro Martin, T. (1990). Changing patterns of remarriage. Journal of Marriage and Family, 52, 747-756. https://doi.org/10 $.2307 / 352939$

Cherlin, A. (1978). Remarriage as an Incomplete Institution. American Journal of Sociology, 84(3), 634-650. https://doi.org/10.1086/226830

Children and Families Act. (2014). Chapter 6. Retrieved from http://www.legislation.gov.uk/ ukpga/2014/6/contents/enacted 
Cm 8273. (2012). The government response to the family justice review: A system with children and families at its heart. Department for Education and Ministry of Justice. London: HMSO.

de Graaf, P. M., \& Kalmijn, M. (2003). Alternative routes in the marriage market: Competing-risk analyses of union formation after divorce. Social Forces, 81(4), 1459-1498. https://doi.org/10.1353/ sof.2003.0052

Dykstra, P. A., \& Poortman, A. R. (2010). Economic resources and remaining single: Trends over time. European Sociological Review, 26(3), 277-290. https://doi.org/10.1093/esr/jcp021

Eggebeen, D. J., \& Knoester, C. (2001). Does fatherhood matter for men? Journal of Marriage and Family, 63(2), 381-393. https://doi.org/10.1111/j .1741-3737.2001.00381.x

Elzinga, C. H., \& Liefbroer, A. C. (2007). De-standardization of family-life trajectories of young adults: A cross-national comparison using sequence analysis. European Journal of Population, 23(3-4), 225-250. https://doi.org/10 .1007/s10680-007-9133-7

Gałęzewska, P., Perelli-Harris, B., \& Berrington, A. (2017). Cross-national differences in women's repartnering behaviour in Europe: The role of individual demographic characteristics. Demographic Research, 37, 189-228. https://doi.org/10.4054/ DemRes.2017.37.8

Gelissen, J. (2004). Assortative mating after divorce: A test of two competing hypotheses using marginal models. Social Science Research, 33(3), 361-384. https://doi.org/10.1016/j.ssresearch.2003.06.003

Goldscheider, F., Kaufman, G., \& Sassler, S. (2009). Navigating the "new" marriage market. Journal of Family Issues, 30, 719-737. https://doi.org/10 $.1177 / 0192513$ X09331570

Goldscheider, F., \& Sassler, S. (2006). Creating stepfamilies: Integrating children into the study of union formation. Journal of Marriage and Family, 68, 275-291. https://doi.org/10.1111/j.1741-3737 .2006.00252.x

Harding, M., \& Newnham, A. (2015). How do county courts share the care of children between parents? Family Law, 45(9), 1021-2262. Retrieved from http://www.nuffieldfoundation.org/sites/default/ files/files/Full\%20report.pdf

Haux, T., Platt, L., \& Rosenberg, R. (2015). Parenting and post-separation contact: What are the links? Retrieved from http://sticerd.lse.ac.uk/dps/ case/cp/casepaper189.pdf

Hofferth, S. L., \& Anderson, K. G. (2003). Are all dads equal? Biology versus marriage as a basis for paternal investment. Journal of Marriage and Family, 65(1), 213-232. https://doi.org/10.1111/j .1741-3737.2003.00213.x

Huerta, C., Adema, W., Baxter, J., Han, J., Lausten, M., Lee, R., \& Waldfogel, J. (2013). Fathers' leave, fathers' involvement and child development:
Are they related? Evidence from four OECD countries (OECD Social, Employment and Migration Working Papers No. 140). Paris: OECD Publishing. https://doi.org/10.1787/5k4dlw9w6czq-en

Hunt, J., \& Roberts, C. (2004). Child contact with non-resident parents (Family Policy Briefing 3). Oxford, UK: University of Oxford Press.

Ivanova, K., Kalmijn, M., \& Uunk, W. (2013). The effect of children on men's and women's chances of re-partnering in a European context. European Journal of Population, 29(4), 417-444. https://doi .org/10.1007/s10680-013-9294-5

Jansen, M., Wijckmans, B., \& Van Bavel, J. (2009). Divorce and the cumulated fertility of men and women across Europe. Retrieved from http://www.vub.ac.be/SOCO/demo/papersonline/ IDWP2009-1.pdf

Kalmijn, M. (1998). Intermarriage and homogamy: Causes, patterns, trends. Annual Review of Sociology, 24, 395-421. https://doi.org/10.1146/annurev .soc. 24.1 .395

Kaufman, G. (2000). Do gender role attitudes matter? Family formation and dissolution among traditional and egalitarian men and women. Journal of Family Issues, 21, 128-144. https://doi.org/ 10.1177/019251300021001006

Kielty, S. (2006). Mothers are nonresident parents too: A consideration of mother's perspectives on nonresidential parenthood. Journal of Social Welfare and Family Law, 27(1), 1-16. https://doi.org/ 10.1080/09649060500085487

Kiernan, K. E. (1992). The impact of family disruption in childhood on transitions made in young adult life. Population Studies, 46(2), 213-234. https://doi.org/10.1080/0032472031000146206

Koo, H. P., Suchindran, C. M., \& Griffith, J. D. (1984). The effects of children on divorce and re-marriage: A multivariate analysis of life table probabilities. Population Studies, 38(3), 451-471. https://doi.org/10.1080/00324728.1984 .10410303

Lampard, R., \& Peggs, K. (1999). Repartnering: The relevance of parenthood and gender to cohabitation and remarriage among the formerly married. The British Journal of Sociology, 50(3), 443-465. https://doi.org/10.1080/000713199358644

Lappegård, T., \& Rønsen, M. (2013). Socioeconomic differences in multipartner fertility among Norwegian men. Demography, 50(3), 1135-1153. https:// doi.org/10.1007/s 13524-012-0165-1

Leckie, G., \& Charlton, C. (2012). runmlwin: A program to run the MLwiN multilevel modeling software from within Stata. Journal of Statistical Software, 52(11), 1-40. Retrieved from http:// www.jstatsoft.org/

Liefbroer, A. C., \& Elzinga, C. H. (2012). Intergenerational transmission of behavioural patterns: How similar are parents' and children's demographic trajectories? Advances in Life Course Research, 
17(1), 1-10. https://doi.org/10.1016/j.alcr.2012.01 .002

Monte, L. M. (2007). Blended but not the Bradys: Navigating unmarried multiple partner fertility. In P. England \& K. Edin (Eds.), Unmarried couples with children (pp. 183-203). New York: Russell Sage. Retrieved from http://www.jstor.org/stable/ 10.7758/9781610441865

Murphy, M. (2000). Editorial: Cohabitation in Britain. Journal of the Royal Statistical Society: Series A, 163(2), 123-126. https://doi.org/10.1111/1467985X.00161

Nock, S. L. (1995). A comparison of marriages and cohabiting relationships. Journal of Family Issues, 16, 53-76. https://doi.org/10.1177/ 019251395016001004

Peacey, V., \& Hunt, J. (2009). I'm not saying it was easy ... Contact problems in separated families. London, UK: Gingerbread.

Perelli-Harris, B. (2014). How similar are cohabiting and married parents? Second conception risks by union type in the United States and across Europe. European Journal of Population, 30(4), 437-464. https://doi.org/10.1007/s10680-014-9320-2

Perelli-Harris, B., Kreyenfeld, M., Sigle-Rushton, W., Keizer, R., Lappegård, T., Jasilioniene, A., \& Di Giulio, P. (2012). Changes in union status during the transition to parenthood in eleven European countries, 1970s to early 2000s. Population Studies: A Journal of Demography, 66(2), 167-182. https://doi.org/10.1080/00324728.2012.673004

Poole, E., Speight, S., O'Brien, M., Connolly, S., \& Aldrich, M. (2015). Who are non-resident fathers? A British socio-demographic profile. Journal of Social Policy, 45(2), 223-250. https://doi.org/10 $.1017 /$ S0047279415000653

Poortman, A. R. (2007). The first cut is the deepest the role of the relationship career for union formation. European Sociological Review, 23(5), 585-598. https://doi.org/10.1093/esr/jem024

Sanchez Gassen, N., \& Perelli-Harris, B. (2015). The increase in cohabitation and the role of union status in family policies: A comparison of 12 European countries. Journal of European Social Policy, 25, 431-449. https://doi.org/10.1177/ 0958928715594561

Skew, A., Evans, A., \& Gray, E. (2009). Repartnering in the United Kingdom and Australia. Journal of Comparative Family Studies, 40(4), 563-585.

South, S. J. (1991). Sociodemographic differentials in mate selection preferences. Journal of Marriage and the Family, 53, 928-940. https://doi.org/10 $.2307 / 352998$

Steele, F. (2008). Multilevel models for longitudinal data. Journal of the Royal Statistical Society. Series A, 171(1), 5-19. https://doi.org/10.1111/j $.1467-985 X .2007 .00509 . x$

Steele, F. (2011). Multilevel discrete-time event history models with applications to the analysis of recurrent employment transitions. Australian and New Zealand Journal of Statistics, 53(1), 1-20. https://doi.org/10.1111/j.1467-842X.2011 $.00604 . x$

Steele, F., Kallis, C., Goldstein, H., \& Joshi, H. (2005). The relationship between childbearing and transitions from marriage and cohabitation in Britain. Demography, 42(4), 647-673. https://doi .org/10.1353/dem.2005.0038

Stewart, S. D. (2005). How the birth of a child affects involvement with stepchildren. Journal of Marriage and Family, 67, 461-473. https://doi.org/10 $.1111 / \mathrm{j} .0022-2445.2005 .00128 . x$

Stewart, S. D., Manning, W. D., \& Smock, P. J. (2003). Union formation among men in the U.S.: Does having prior children matter? Journal of Marriage and Family, 65, 90-104. https://doi.org/10.1111/j .1741-3737.2003.00090.x

Sweeney, M. M. (1997). Remarriage of women and men after divorce the role of socioeconomic prospects. Journal of Family Issues, 18, 479-502. https://doi.org/10.1177/019251397018005002

Sweeney, M. M. (2010). Remarriage and stepfamilies: Strategic sites for family scholarship in the 21st century. Journal of Marriage and Family, 72, 667-684. https://doi.org/10.1111/j.1741-3737 .2010.00724.x

Tavares, L. P., \& Aassve, A. (2013). Psychological distress of marital and cohabitation breakups. Social Science Research, 42(6), 1599-1611. https://doi.org/10.1016/j.ssresearch .2013 .07 .008

Trinder, L. (2010). Shared residence: A review of recent research evidence. Child and Family Law Quarterly, 22(4), 475-498. Retrieved from https://heinonline.org/HOL/P?h=hein.journals/ chilflq22\&i $=483$

United Nations Educational, Scientific and Cultural Organization. (2011). International standard classification of education. Paris: UNESCO.

Upchurch, D. M., Lillard, L. A., \& Panis, C. W. A. (2002). Nonmarital childbearing: Influences of education, marriage, and fertility. Demography, 39(2), 311-329. https://doi.org/10.1353/dem.2002 .0020

Vanassche, S., Corijn, M., Matthijs, K., \& Swicegood, G. (2015). Repartnering and childbearing after divorce: Differences according to parental status and custodial arrangements. Population Research and Policy Review, 34(5), 761-784. https://doi.org/ 10.1007/s11113-015-9366-9

Wang, H., \& Amato, P. R. (2000). Predictors of divorce adjustment: Stressors, resources, and definitions. Journal of Marriage and Family, 62, 655-668. https://doi.org/10.1111/j.1741-3737 $.2000 .00655 . x$

Waynforth, D. (2013). Evolutionary perspectives on father involvement. In N. J. Cabrera \& C. S. Tamis-LeMonda (Eds.), Handbook of father 
involvement: Multidisciplinary perspectives (pp. 23-36). New York, NY: Routledge.

Winkler-Dworak, M., \& Toulemon, L. (2007). Gender differences in the transition to adulthood in France: Is there convergence over the recent period? European Journal of Population, 23,
273-314. https://doi.org/10.1007/s10680-0079128-4

Wu, Z., \& Schimmele, C. M. (2005). Repartnering after first union disruption. Journal of Marriage and Family, 67, 27-36. https://doi.org/10.1111/j $.0022-2445.2005 .00003 . x$ 